\title{
Financial Access of Unorganised Manufacturing Enterprises in Assam
}

Mr Prasenjit Bujar Baruah ${ }^{\dagger}$

\section{Abstract}

The unorganised sector is no more considered as a residual one in the developing and in the underdeveloped countries; rather it is considered as a common component of such economies. This sector is playing an important role in those countries both in terms of its contribution to the national income and employment generation. However, despite its importance, the enterprises in this sector are facing various problems. A large segment of enterprises state non-accessibility to credit is the most important problem faced by them. Moreover, existing reports and literature states that the formal financial institutions are not interested to deal with the unorganised enterprises. As a result, they have to depend on the informal sources of credit. This present paper based on secondary data analyses the various characteristics of unorganised manufacturing enterprises in Assam and their accessibility to credit. Results indicate that the average amount of outstanding loan per unorganised manufacturing enterprise in Assam is smaller than that of allIndia average. Again, the enterprises in the rural areas are more dependent on the noninstitutional sources of credit when compared to those in the urban areas. Similarly, the smaller enterprises have limited access to credit from the formal financial institutions as compared to the larger enterprises.

Key words: unorganised enterprise, manufacturing, financial access, financial resource gap and credit

\footnotetext{
${ }^{\dagger}$ Assistant Professor, Department of Economics, Rajiv Gandhi University, Rono Hills, Doimukh, Arunachal Pradesh791112; Mob: 094010-45756, Email: prasenjitbb@gmail.com (C)2014 Bujar Baruah. This is an Open Access article distributed under the terms of the Creative Commons Attribution License (http://creativecommons.org/licenses/by/2.0), which permits unrestricted use, distribution, and reproduction in any medium, provided the original work is properly cited.
} 


\section{Introduction}

The unorganised sector has attracted the attention of the theoreticians and the researchers in the dynamics of development economics since long back. Those economic activities taking place outside the organised sector are termed as informal sector by the international organisations like International Labour Organisation (ILO). In India, this segment of the economy is generally termed as the unorganised sector. Moreover, the National Sample Survey Organization (NSSO) in India makes differentiation between the unorganised and the informal sector. This definition makes the informal sector a sub-set of the unorganised sector. Earlier, this section of economic activities was regarded as a residual sector. It was assumed that along with economic development, those engaged in this sector would be able to absorb themselves in the organised sector (Harish \& Todaro, 1970). However, currently it is considered as a common component of the developing and underdeveloped economies; where it is playing an important role both in terms of its contribution to national income and employment generation. Nevertheless, the enterprises in this sector are facing various problems, such as small and fluctuating level of income, lack of skill, use of poor technology and non-accessibility to capital, etc. Among these non-availability of credit is regarded as the most important one (Honorati et al., 2007); as other problems such as lack of technology (Bhavani, 2006) or skill formation are also related to access to adequate amount of credit. Major segment of the unorganised enterprises do not have access to credit and other financial services due to their inability to pay higher interest rate, meet collateral requirements, and cope with plethora of procedure and formalities (Subramanian, 2012). One segment of literature states that, the access of small enterprises to capital market was limited because of greater behavioural risk of default and higher lending cost (Bhavani and Tendulkar, 1997). As a result, the internal funding (Allen et al., 2006) and credit from the non- institutional sources constitutes the major source of funding for these enterprises. Based on this information, this paper tries to address the following objectives:

- To examine the nature and importance of the unorganised manufacturing enterprises in Assam.

- To analyse the financial accessibility of unorganised manufacturing enterprises in Assam.

\section{Data Source and Methodology}

The unorganised sector is a heterogeneous one, comprising of unorganised workers and enterprises. Moreover, this sector includes both the farm and non-farm activities. Again, the non-farm sector includes both the manufacturing as well as service sector enterprises. However, the nature and characteristics of the enterprises in the farm sector are quite different from those in the non-farm sector and the service sector within the non-farm sector is also a highly heterogeneous one. Moreover, as the research concentrates in a particular area, this paper deals with the manufacturing enterprises only.

The concept of financial access is widely discussed in the existing literatures. The World Bank (2008) considers financial inclusion or financial access as the availability of financial services to all without any barrier. Thus, financial access is a broader concept that includes those using financial services and those who are voluntarily excluded. Indeed, it is a supply side concept, but due to the difficulty to differentiate between the voluntary and non-voluntary exclusion from financial services, Bhavani et al., (2012) measured financial accessibility as the actual availability and adequacy of loan from Formal Financial Institutions (FFIs). They used the concept of Financial Resource Gap (FRG) ${ }^{1}$ to measure the adequacy of credit. FRG indicates the percentage of loan taken by an enterprise (or

\footnotetext{
${ }^{1}$ Financial Resource Gap indicates the proportion of loan taken by the enterprises from the non-institutional sources i.e., $F R G=$ (Amount of Loan taken from noninstitutional Sources/Total Amount of Loan) (cited in Bhavani et al., 2012, pp.9).
} 
an individual) from the non-institutional sources. This research also tries to analyse the unorganised enterprise's accessibility to financial services using the concept of FRG.

This research is based on secondary data that are compiled from different rounds of NSSO surveys, Economic Survey of Assam, Statistical Hand Book, Assam and the internet. In India, NSSO is the principal source of data for the unorganised sector. However, the concepts and coverage of the surveys change from time to time. That is why; the data are not strictly comparable over the years. Therefore, this is one of the major limitations of this research.

This research examines unorganised manufacturing enterprises in Assam a relatively backward states in India, with higher rate of unemployment. Although the economy of this state is basically an agrarian, the non-farm sector is also emerging in the recent years. The agricultural productivity in this state is very low and the overall condition of the organised industrial sector is also not satisfactory. Thus, the non-farm unorganised sector is expected to play an important role in this state. Existing literature and reports also indicate that the overall indebtedness of households and enterprises is relatively lower in this state when compared to the rest of country. Moreover, the overall FRG in Assam is sufficiently inadequate (Bhavani et al., 2012). Therefore, this research is an attempt to concentrate in only in Assam.

This research consists of four sections: following the introduction, it discusses different characteristics and importance of the unorganised manufacturing enterprises in Assam. The third section discusses about the unorganised manufacturing enterprise's access to credit. The fourth and the concluding section summaries the discussion and recommends policy implications.

\section{The Unorganised Manufacturing Enterprises in} Assam

Before discussing other aspects of the unorganised manufacturing enterprises it would be wise to have an idea regarding the definition and coverage of the unorganised enterprises. The 15th International Conference for Labour Statisticians (ICLS) held in January, 1993 for the first time tried to give an inclusive definition of the unorganised/informal enterprises. According to this definition, informal enterprises are those private unincorporated enterprises owned by individual or households who do not have any legal status independent of individual or households who own them. As a result, no complete account of the enterprise is available that enables the financial separation of the enterprise from other activities of its owner. Further, this definition adds that to be regarded as an enterprise, the production or service unit must sale at least a part of its product in the market. Neither the enterprise nor its employees are registered under national legislation. The issue of maximum number of workers employed in such unit is left to the country concern. Noted that this definition includes enterprises belong to the nonagricultural sector only.

In India, the 62nd round of NSSO survey on unorganised manufacturing enterprises, 20052006 defined unorganised enterprise ${ }^{2}$ as all those private enterprises which are not registered under sections $2 \mathrm{~m}$ (i) and $2 \mathrm{~m}$ (ii) of Factories Act, 1948 and Bidi and Cigar workers (Condition of Employment) Act, 1966. Actually, any enterprise in India, employing 10 or more workers with the use of electricity (and 20 or more workers without using electricity) has to register under the Factories Act, 1948. In addition, the Annual Survey of Industries (ASIs) covers these industries. The NSSO's unorganised manufacturing sector survey covers those industries, which are not included in the ASI. Thus, in principle, the NSSO survey on unorganised manufacturing enterprises excludes those enterprises employing 10 or more workers with the use of electricity and 20 or more workers without using electricity. But in reality many bigger units (that is, employing more workers) are not registered under the

\footnotetext{
${ }^{2}$ The 57 th and 63rd rounds of NSSO survey on unorganised service Sector in India also used the same definition to identify an enterprise.
} 
section $2 \mathrm{~m}$ (i) and $2 \mathrm{~m}$ (ii) of Factory Act, 1948 and are excluded from the coverage of ASI. And such, bigger units are also covered by the NSSO unorganised manufacturing enterprise survey. Thus, in India, the unorganised sector is a residual sector and it covers those enterprises for which data from any other regular sources is not available. The NSSO applies the same system to other sections of the unorganised sector too.

Considering the importance of the unorganised sector, the Government of India appointed National Commission for Enterprises in the Unorganised Sector (NCEUS) in 2004 to study different aspects of the unorganised enterprises. The definition provided by this commission (Bhalla, 2009) is a more inclusiveaccording to this commission, unorganised/ informal enterprises are all those unincorporated private enterprises owned by individuals or households engaged in the sale and production of goods and services operated on a proprietary or partnership basis; with less than 10 workers. This definition gave more emphasis on the maximum number of workers employed irrespective of the sector in which they lie. Moreover, the registration of such enterprises was made a flexible criterion.

Having discussed different definitions of unorganised enterprises it is found that nonregistration with some recognised agency, nonmaintaining the accounts of their business and some maximum limit on the number of labour employed are regarded as the characteristics of the unorganised enterprises.

\section{Types of Unorganised Manufacturing Enterprises}

It is now essential to have an idea about the different categories of the unorganised manufacturing enterprises in Assam. The NSSO broadly classified the unorganised manufacturing enterprises into three categories: Own Account Manufacturing Enterprises (OAME), Non-Directory Manufacturing Enterprises (NDME) and Directory Manufacturing Enterprises (DME). OAME are those manufacturing enterprises working without employing any regular worker on a fairly regular basis. NDME are those enterprises employing workers between two to five. And those enterprises that employ more than five workers are known as DME. The total number of different categories of unorganised enterprises in Assam over the years can be shown with the help of the Table 1.

From Table 1, it can be seen that the percentage share of different types of enterprises in the total number of unorganised manufacturing enterprises of Assam is more or less constant over the years. In Assam, the maximum percentage of unorganised manufacturing enterprises belongs to rural area. During 1994-1995 as well as during 20052006, around 90 per cent of the unorganised enterprises were rural enterprises. During 2000-2001, the percentage of rural enterprises decreased to 86 per cent. Again, Assam's share in the total number of unorganised manufacturing enterprises of India decreased from 2.12 per cent during 1994-1995 to 1.64 per cent in 2000-2001; and then it increased to 2.17 per cent in 2005-2006. Assam's share in the total number of rural unorganised manufacturing enterprises in India is relatively higher than that of the urban. Similarly, Assam's share in the smaller units is relatively higher than that of the bigger units.

During the 2010-2011, the NSSO conducted another round of survey of the Unincorporated Non-Agricultural Enterprises (excluding construction) in India. By definition the unincorporated non- agricultural enterprises is a sub set of unorganised enterprises. This survey covered the enterprises from manufacturing, trade and other services categories. All the enterprises surveyed were classified as Own Account Enterprises (OAE) and Establishments. OAE were those enterprises working on a fairly regular basis without employing any workers. And those enterprises employing workers from outside were termed as establishments. This survey also indicated that in Assam, the higher percentage of the unincorporated manufacturing enterprises were rural enterprises. Again, larger number of OAEs 
belonged to the rural areas; relative to that of the establishments.

The unorganised manufacturing enterprises are classified into different categories; which also changed over different rounds of NSSO survey. The 56th and 62nd rounds of NSSO surveys classified the unorganised manufacturing enterprises into 24 categories. These are cotton ginning, cleaning and baling; food products and beverages; tobacco products; textiles; wearing apparels: dressing and dying of fur; tanning and dressing of leather (luggage, handbag, saddler, harness and footwear); wood and products of wood and cork (except furniture), articles of straw and planting materials; paper and paper products; publishing, printing and reproduction of recorded materials; coke, refined petroleum products and nuclear fuel; chemical and chemical products; rubber and plastic products; other non-metallic mineral products; basic metals; fabricated metal products, except machinery and equipment; machinery and equipment (not elsewhere classified); office equipment and computing machinery; electrical machinery and apparatus (not elsewhere classified); radio, television and communication equipments and apparatus; medical precision and optical watches and clocks; motor vehicles, trailers and semi trailers; other transport equipments; furniture manufacturing (not elsewhere classified) and recycling. During 2005-2006, in Assam among the different categories of unorganised manufacturing enterprises, food products and beverages was the largest sub- sector; followed by textile industry and furniture manufacturing sector.

Table 1: Numbers of Unorganised Manufacturing Enterprises in Assam (Figures in the bracket gives per cent value)

\begin{tabular}{llccccc} 
& & OAME (O) & NDME (N) & $\mathbf{O + N}$ & DME & All \\
\hline $\mathbf{1 9 9 4 -}$ & Rural & 244616 & 29450 & 274066 & 776 & 274842 \\
$\mathbf{1 9 9 5}$ & & $(89.00)$ & $(10.72)$ & $(99.72)$ & $(0.28)$ & $(100.00)$ \\
\cline { 2 - 7 } & Urban & 18242 & 12553 & 30795 & 1463 & 32258 \\
& & $(56.55)$ & $(38.92)$ & $(95.46)$ & $(4.54)$ & $(100.00)$ \\
\cline { 2 - 7 } & Rural+ & 262858 & 42003 & 304861 & 2239 & 307100 \\
& Urban & $(85.59)$ & $(13.68)$ & $(99.23)$ & $(0.73))$ & $(100.00)$ \\
\hline $\mathbf{2 0 0 0 -}$ & Rural & 224130 & 14881 & 239010 & 1395 & 240405 \\
$\mathbf{2 0 0 1}$ & & $(93.20)$ & $(6.20)$ & $(99.40)$ & $(0.60)$ & $(100.00)$ \\
& Urban & 23310 & 13339 & 36649 & 1394 & 38043 \\
& & $(61.30)$ & $(35.10)$ & $(96.30)$ & $(3.70)$ & $(100.00)$ \\
\cline { 2 - 7 } & Rural+ & 247440 & 28220 & 275659 & 2789 & 278448 \\
$\mathbf{2 0 0 5 -}$ & Urban & $(88.90)$ & $(10.10)$ & $(99.00)$ & $(1.00)$ & $(100.00)$ \\
$\mathbf{2 0 0 6}$ & Rural & 306157 & 24581 & 330738 & 2268 & 333006 \\
& & $(91.94)$ & $(7.38)$ & $(99.32)$ & $(0.68)$ & $(100.00)$ \\
\cline { 2 - 7 } & Urban & 21984 & 13647 & 35631 & 2143 & 37774 \\
& & $(58.20)$ & $(36.13)$ & $(94.32)$ & $(5.68)$ & $(100.00)$ \\
\cline { 2 - 7 } & Rural+ & 328142 & 38228 & 366370 & 4411 & 370781 \\
& Urban & $(88.50)$ & $(10.30)$ & $(98.81)$ & $(1.19)$ & $(100.00)$ \\
\hline
\end{tabular}

Sources: Compiled from Report No.434, Unorganised Manufacturing Enterprises in India: Silent Features, NSS 51st Round, 1994-95; Report No. 478, Unorganised Manufacturing Sector in India: Characteristics of Enterprises, NSS 56th Round, 2000-01 and Report No.524, Operational Characteristics of unorganised Manufacturing Enterprises in India, NSS 62nd Round, 2005-06 
During the same period, in Assam, none of the unorganised enterprises lies into the categories such as manufacturing of coke, refined petroleum products and nuclear fuel, manufacturing of office equipment and computing machinery, manufacturing of radio, television and communication equipments and apparatus, manufacturing of medical precision and optical watches and clock, manufacturing of motor vehicles, trailers and semi- trailers and recycling.

\section{Unorganised Enterprises Not Registered with any Agency}

One of the important characteristics of unorganised enterprise is their status of registration. One segments of reports and literature categories those enterprises as unorganised which are not registered under some specific laws of the country concern. The 15th International Conference of Labour Statisticians (ICLS) left this issue to the country concern whether registration should be the basis for categorising enterprises as organised or unorganised.

In India, those manufacturing enterprises that are not registered under section $2 \mathrm{~m}$ (i) and $2 \mathrm{~m}$ (ii) of Factories Act, 1948 and Bidi and Cigar
Workers (Condition of Employment) Act, 1966 are regarded as the unorganised enterprises. However, there are some other agencies too, where the unorganised (as well as the organised) enterprises may register themselves. For example, an enterprise may register itself with the District Industries Centre (DIC) as Small scale Industry. Other such agencies where an enterprise may register are Khadi and Village Industry Commission; Development Commissioner of Handicrafts; Development Commissioner of Handloom; Coir Board; Silk Board; Jute Commission; Municipal Corporation, Panchayat, Local Body; Section 85 of Factories Act, 1948. It should be noted however that, registration with these agencies do not necessarily make an enterprise the organised. Sometimes, the same enterprise may be registered with the more than one agency.

In India, the registration status becomes necessary for an enterprise to have assistance from the government. For example, if an industry has to avail any benefit from the Ministry of Micro, Small and Medium Enterprises (MSME), it needs to be registered with the District Industries Centre (DIC). The distribution of the enterprises according to their status of registration in Assam can be explained with the help of Table 2.

Table 2: Distribution of the Unorganised Manufacturing Enterprises not Registered with any Agency (in per cent)

\begin{tabular}{lcccccc} 
& \multicolumn{3}{c}{$\mathbf{2 0 0 0 - 2 0 0 1}$} & \multicolumn{3}{c}{$\mathbf{2 0 0 5 - 2 0 0 6}$} \\
\cline { 2 - 7 } & Rural & Urban & Rural + Urban & Rural & Urban & Rural + Urban \\
\hline OAME & 97.6 & 81.4 & 94.2 & 97.8 & 77.9 & 96.4 \\
\hline NDME & 71.8 & 44.1 & 58.7 & 92.3 & 31.2 & 70.5 \\
\hline DME & 53.1 & 37.0 & 45.0 & 53.4 & 61.5 & 57.3 \\
\hline All & 93.8 & 66.7 & 90.1 & 97.1 & 60.1 & 93.3
\end{tabular}

Sources: Compiled and calculated from Report No. 478, Unorganised Manufacturing Sector in India: Characteristics of Enterprises, NSS 56th Round, 2000-2001 and Report No.524, Operational Characteristics of unorganised Manufacturing Enterprises in India, NSS 62nd Round, 2005-2006

From the above Table it is apparent that the lion's share of the unorganised manufacturing enterprises is not registered with any agency. Higher percentage of manufacturing enterprises located in the urban areas fulfils the registration criteria compared to those in the rural areas. Similarly, the probability of fulfilling the registration criteria increases as the size of the enterprise increases. NSSO 67th (July 2010June 2011) round also indicates that more than 87 per cent of unincorporated manufacturing enterprises in Assam are not registered with 
any agency; which is slightly higher than the allIndia figure.

In Assam, the largest percentage of unorganised manufacturing enterprises is registered with the Municipal Corporation, the Panchayats and other local bodies; followed by those registered with the DICs. Although Assam is rich in the weaving of silk and other forms of handlooms and handicrafts, no industry is found to be registered with Silk Board, Development Commissioner of Handlooms and Development Commissioner of Handicrafts.

\section{Enterprises Not Maintaining Any Account of Their Business}

The 15th ICLS defined those enterprises as informal, which do not keep any account of their activities and as a result, they could not be separated from the other activities of the entrepreneur. Thus, information regarding maintenance of their accounts is also of importance. The percentage distribution of unorganised manufacturing enterprises in Assam those do not maintain any account of their business can be explained with the help of the following Table 3.

Table 3: Distribution of Those Enterprises that do not Maintain Their Accounts (in per cent)

\begin{tabular}{lcccccc} 
& \multicolumn{3}{c}{$\mathbf{2 0 0 0 - 2 0 0 1}$} & \multicolumn{3}{c}{$\mathbf{2 0 0 5 - 2 0 0 6}$} \\
\cline { 2 - 7 } & Rural(R) & Urban(U) & R+U & Rural & Urban & $\mathrm{R}+\mathrm{U}$ \\
\hline OAME & 99.5 & 97.7 & 99.3 & 97.5 & 97.3 & 97.5 \\
\hline NDME & 88.4 & 94.7 & 91.4 & 83.5 & 85.1 & 84.1 \\
\hline DME & 68.4 & 75.5 & 71.9 & 53.7 & 80.0 & 66.5 \\
\hline All & 98.6 & 95.9 & 98.3 & 96.2 & 91.9 & 95.8
\end{tabular}

Sources: Compiled and calculated from Report No. 478, Unorganised Manufacturing Sector in India: Characteristics of Enterprises, NSS 56th Round, 2000-2001 and Report No.524, Operational Characteristics of unorganised Manufacturing Enterprises in India, NSS 62nd Round, 2005-2006

Table 3 shows that the percentage of enterprises that do not maintain any accounts of their business separately is declining over the years. Almost all the OAME do not maintain any account of their business separately. Similarly, larger percentage of the rural enterprises does not keep any account of their business compared to the urban enterprises. Higher percentage of DME keeps their accounts separately and within the DME, relatively higher percentage of rural enterprises keeps their accounts separately. The 67th round of NSSO survey reveals that more than 97.1 per cent of the unorganised manufacturing enterprises in Assam do not keep any record of their accounts.

\section{Number of Workers Employed in the Enterprise}

Some definite (maximum) number of workers employed by an enterprise is also considered as a criterion to classify the enterprises as an unorganised one. As stated above, the 15th ICLS left this issue to the accounting authority of the country concern. Therefore, it is reiterated that in India, the NSSO's unorganised manufacturing sector survey in principle covers those enterprises employing less than 10 workers with the use of electricity and less than 20 workers without using electricity. However, in reality the NSSO does not put any limit on the maximum number of workers employed in an unorganised unit. NCEUS classified that all those private, unincorporated units in the manufacturing as well as in the service sector as unorganised enterprise that employ less than ten workers. Thus, the numbers of workers employed by an enterprise is an important characteristic in case of the unorganised sector. The distribution of unorganised manufacturing enterprises according to the number of workers employed by them is shown in Table 4.

As can be seen from the Table 4 that majority of the unorganised manufacturing enterprises are employing less than five workers; although the percentage of enterprises employing larger number of workers is increasing over the years. 
By definition, OAMEs do not employ any workers on a fairly regular basis; while the NDMEs employ 2 to 5 workers on a fairly regular basis. But from Table 4 it can be seen that maximum percentage of OAMEs are employing 2 to 5 workers over the years and during 2005-2006 even 0.40 per cent of them were employing more than 10 workers.

Table 4: Distribution of Enterprises According to Number of Workers Employed (in per cent)

\begin{tabular}{llcccc}
\hline $\mathbf{2 0 0 0 - 2 0 0 1}$ & & $\mathbf{1}$ & $\mathbf{2}$ to $\mathbf{5}$ & $\mathbf{6}$ to $\mathbf{9}$ & $\mathbf{1 0} \leq$ \\
& OAME & 49.80 & 50.20 & 0.00 & 0.00 \\
\cline { 2 - 6 } & NDME & 0.40 & 98.80 & 0.80 & 0.00 \\
\cline { 2 - 6 } & DME & 0.00 & 0.00 & 68.30 & 31.70 \\
\cline { 2 - 6 } & All & 44.30 & 55.60 & 0.80 & 0.30 \\
\hline & OAME & 43.00 & 56.60 & 0.00 & 0.40 \\
\cline { 2 - 6 } & NDME & 0.00 & 94.00 & 4.40 & 1.60 \\
\cline { 2 - 6 } & DME & 0.00 & 2.00 & 30.40 & 67.60 \\
\cline { 2 - 6 } & All & 32.10 & 59.40 & 3.00 & 5.50
\end{tabular}

Sources: Compiled and calculated from Report No. 479, Unorganised Manufacturing Sector in India: Employment, Assets and Borrowings, NNS 56th Round, 2000-2001; Report No. 526, Unorganised Manufacturing Sector in India: input, output and Value Added, NSS 62nd Round, 2005-2006

Importance of the Unorganised Manufacturing Enterprises in Assam

It is already mentioned that the unorganised enterprises are playing an important role in the developing and in the underdeveloped countries. The story is not exceptional in the case of Assam. In Assam, the unorganised manufacturing enterprises have a significant share in the Gross State Domestic Product (GSDP) and are also employing large number of workers. During 1994-1995, the unorganised manufacturing enterprises were contributing 1.93 per cent to the GSDP of Assam; which increased to 2.13 per cent per cent during 2000-2001. This percentage share increased to 2.29 per cent during 2005-2006 and then it decreased to 1.95 per cent per cent during 2010-2011. As the coverage of the survey is changed over the years, the data belonging to different years is not strictly comparable. However, the coverage of the survey made during 2000-2001 and 2005-2006 are similar; so it can be concluded that the share of the unorganised manufacturing enterprises in the GSDP of Assam increased during this period. Again, the major percentage of this contribution comes from the rural enterprises.
Here it remains important to have an idea about the productivity of these enterprises, that is, Gross Value Added (GVA) per enterprise in this sector. The GVA per unorganised manufacturing enterprise increased from ₹29, 370 to ₹36, 725 during 2000-2001 and 20052006. During 2010-2011, GVA per unorganised manufacturing enterprise was $₹ 100,240$, which was found to be higher among the urban enterprises. Moreover, the GVA per enterprise is increasing along with the increase in the size of the enterprise.

Unorganised enterprises are the employer of a large number of unskilled and semi-skilled labourers. Total number of workers employed in the unorganised manufacturing enterprises increased from 4, 98, 830 to 6, 32, 481 during 2000-2001 and 2005-2006. Larger percentage of workers was found to be employed in the rural sector. During 2010-2011, the number workers employed in the unincorporated manufacturing enterprises were $4,22,025$. This decreased number is probably due to the changed in the definition and coverage of this survey. Along with the number of workers employed, the productivity of the workers is also of importance. The GVA per worker increased from ₹ 16,395 to ₹ 21,529 during 2000-2001 and 2005-2006. The GVA per worker 
in Assam is lower than that of the all-India average (₹24,034 during 2005-2006). Again, the GVA per worker increased along with the increased size of the enterprise.

From this discussion, it is clear that the unorganised manufacturing enterprises are playing an important role in Assam. However, existing reports and literature state that the enterprises in this sector are facing various problems such as small and fluctuating level of income, lack of skill, use of poor technology and non-accessibility to capital, etc. Among these, non-availability of credit is regarded as the most important one; as other problems such as lack of technology or skill formation are also related to availability of adequate amount of credit. As a result, internal funding and credit from the non-institutional sources constitute the major source of funding for these enterprises. This information inspires to have an investigation into the financial accessibility of the unorganised manufacturing enterprises in Assam, which is done in the following section.

\section{Financial Access of Unorganised Manufacturing Enterprises}

Access to finance is one of the pre-requisites for any enterprises to work smoothly. The World Bank (2008) considers financial inclusion or financial access as the availability of financial services to all without any barrier. In other words, financial access indicates timely availability of adequate amount of credit and other financial services to all at an affordable cost. Thus, access to finance is a broader concept which includes access to savings, credit and insurance services. However, considering the limited scope of this research, it deals only with access to credit. An entrepreneur needs credit for different purposes. Debraj Ray (2000) classified the purposes of credit into three categories: capital expenditure, working capital expenditure and finally, consumption expenditure. According to him, capital expenditure is that part of the expenditure made to start up new businesses or for large- scale expansion of the existing one. Expenditure on working capital includes the ongoing production expenditures like raw materials or labour cost. Sometimes an entrepreneur may also borrow for consumption purposes. Again, the consumption expenditure can be divided into two categories, that is, current consumption expenditure and expenditure on consumer durables.

Notwithstanding, a large segment of existing reports and literature state, that the unorganised enterprises do not have access to credit. Different rounds of NSSO surveys also indicate that larger percentage of unorganised manufacturing enterprises in Assam as well as in India stated shortage of capital as the main constraint faced by them. For example, during 2000-2001, 73.8 per cent of the unorganised manufacturing enterprises in Assam stated shortage of capital as the constraint faced by them. Similarly, during 2005-2006, 67.3 per cent of unorganised manufacturing enterprises in Assam stated shortage of capital as their key constraints. The outstanding amount of loan per unorganised manufacturing enterprises in Assam can be explained with the help of the Table 5.

From the data in Table 5, it can be seen that the amount of loan per enterprise increased over the years. The average amount of loan per enterprise increased from ₹700 during 20002001 , to that of ₹1367 during 2005-2006. Such an increase in the average amount of loan per enterprise was found for all types of enterprises. Again, the average amount of loan per enterprise was found to be increased along with the increase in the size of the enterprise. For example, during 2005-2006 the average amount of loan per DME was ₹73, 022. During the same period, the average amount of loan was ₹182 and ₹3, 271 respectively per OAME and NDME. The average amount of loan per enterprise is higher in the case of unban unorganised enterprises compared to that of the rural ones. 
Table 5: Outstanding Amount (in ₹) of Loan per Unorganised Manufacturing Enterprise in Assam

\begin{tabular}{ccccccccccccc} 
& \multicolumn{3}{c}{ OAME } & \multicolumn{3}{c}{ NDME } & \multicolumn{3}{c}{ DME } & & \multicolumn{3}{c}{ All } \\
\cline { 2 - 5 } & $\begin{array}{c}\text { Rurban } \\
(\mathrm{R})\end{array}$ & $\mathrm{R}+\mathrm{U})$ & $\mathrm{R}$ & $\mathrm{U}$ & $\mathrm{R}+\mathrm{U}$ & $\mathrm{R}$ & $\mathrm{U}$ & $\mathrm{R}+\mathrm{U}$ & $\mathrm{R}$ & $\mathrm{U}$ & $\mathrm{R}+\mathrm{U}$ \\
\hline $\begin{array}{c}\mathbf{1 9 9 4 -} \\
\mathbf{1 9 9 5}\end{array}$ & 106 & 344 & $\mathrm{NA}$ & 1804 & 1894 & $\mathrm{NA}$ & 9219 & 23818 & $\mathrm{NA}$ & 313 & 2011 & $\mathrm{NA}$ \\
\hline $\mathbf{2 0 0 0}-$ & 133 & 216 & 141 & 2397 & 2684 & 2533 & 53010 & 10550 & 31784 & 580 & 1460 & 700 \\
$\mathbf{2 0 0 1}$ & & & & & & & & & & & & \\
\hline $\mathbf{2 0 0 5}-$ & 174 & 293 & 182 & 1796 & 5928 & 3271 & 72990 & 73057 & 73022 & 790 & 6457 & 1367 \\
$\mathbf{2 0 0 6}$ & & & & & & & & & & & &
\end{tabular}

Sources: Compiled and calculated from Report No. 435: Assets and Borrowings of the Unorganised Manufacturing Enterprises in India, NSS 51st Round, 1994-1995; Report No.479, Unorganised Manufacturing Sector in India: Employment, Assets and Borrowings, NNS 56th Round, 2000-2001 and Report No.525, Unorganised Manufacturing Sector in India: Employment, Assets and Borrowings, NSS 62nd Round, 2005-2006

During 2010-2011, the outstanding amount of loan per manufacturing enterprise in Assam was found to be ₹978. During the same period, the outstanding amount of loan per OAME is as low as ₹66, while that of per establishment enterprise is ₹3339.

Information about outstanding amount of loan only is not sufficient to understand the financial health of an enterprise. To have a clearer idea about it, information about fixed asset of the entrepreneurs is also important. This is because entrepreneurs with a higher level of fixed asset have the capacity to borrow higher amount of money. Thus, outstanding amount of loan as a percentage of fixed assets of an entrepreneur can give a clearer picture of the financial status of the unorganised enterprises. The outstanding amount of borrowing per unorganised manufacturing enterprise as a percentage of their fixed asset can be explained with the help of the Table 6.

Table 6: Outstanding Amount of Loan per Unorganised Manufacturing Enterprise as a Percentage of their Fixed Asset

\begin{tabular}{|c|c|c|c|c|c|c|c|c|c|c|c|c|}
\hline & \multicolumn{3}{|c|}{ OAME } & \multicolumn{3}{|c|}{ NDME } & \multicolumn{3}{|c|}{ DME } & \multicolumn{3}{|c|}{ All } \\
\hline & $\begin{array}{c}\text { Rural } \\
\text { (R) }\end{array}$ & $\begin{array}{l}\text { Urban } \\
\text { (U) }\end{array}$ & $\mathrm{R}+\mathrm{U}$ & $\mathrm{R}$ & $U$ & $\mathrm{R}+\mathrm{U}$ & $\mathrm{R}$ & $U$ & $\mathrm{R}+\mathrm{U}$ & $\mathrm{R}$ & $U$ & $\mathrm{R}+\mathrm{U}$ \\
\hline $\begin{array}{c}1994- \\
1995\end{array}$ & 1.65 & 4.14 & NA & 7.82 & 6.74 & NA & 10.89 & 47.42 & NA & 3.72 & 11.23 & NA \\
\hline $\begin{array}{c}2000- \\
2001\end{array}$ & 1.28 & 0.88 & 1.20 & 5.43 & 3.48 & 4.24 & 20.48 & 4.54 & 12.94 & 4.16 & 2.88 & 3.69 \\
\hline $\begin{array}{l}2005- \\
2006\end{array}$ & 1.25 & 0.58 & 1.11 & 3.23 & 4.43 & 3.91 & 16.19 & 13.93 & 15.01 & 3.96 & 6.01 & 4.74 \\
\hline $\begin{array}{l}\text { Sources } \\
\text { Unorga } \\
\text { Unorga } \\
\text { Round, } \\
\text { Assets }\end{array}$ & $\begin{array}{l}\text { Comp } \\
\text { sed } M \\
\text { sed } M \\
000-20 \\
\text { id Borr }\end{array}$ & $\begin{array}{l}\text { d anc } \\
\text { lufactı } \\
\text { ufact } \\
\text { and } F \\
\text { vings. }\end{array}$ & or & $\begin{array}{l}\text { ted } \\
\text { erpr } \\
\text { tor } \\
.52\end{array}$ & $\begin{array}{l}\text { om } \\
\text { s in } \\
\text { Ind } \\
\text { Ino }\end{array}$ & $\begin{array}{l}\text { dia, } \\
\text { Em } \\
\text { nise }\end{array}$ & $\begin{array}{l}\text { No. } 4 \\
\text { is } 51 s \\
\text { ymen }\end{array}$ & $\begin{array}{l}\text { 5: As } \\
\text { Roun } \\
\text { Asse } \\
\text { cturin }\end{array}$ & and & $\begin{array}{l}\text { Borr } \\
95 ;\end{array}$ & $\begin{array}{l}\text { vings } \\
\text { port } \\
\text { ss, NA } \\
\text { Emplc }\end{array}$ & $\begin{array}{l}\text { the } \\
479, \\
66 \text { th } \\
\text { ent, }\end{array}$ \\
\hline
\end{tabular}

Table 6 illustrates, that the outstanding amount of loan as a percentage of their fixed asset is not very high among the unorganised manufacturing enterprises. The debt asset ratio declined during 1994-1995 and 2000-2001; then it slightly increased during 2005-2006.
Again, the debt asset ratio is found to increase along with the increase in the size of the enterprises. There is no clear indication whether rural or urban enterprises have higher debt asset ratio. However, it could be concluded that as the overall debt asset ratio is 
not very high among the unorganised manufacturing enterprises, they have the potentiality to have higher amount of borrowing.

From the above analysis, it can be clearly seen that the average amount of outstanding loan per unorganised manufacturing enterprise is lower than the potentiality they have to borrow. Here queries arise whether it is due to lack of demand for or supply of credit. This could be partially answered with the help of information regarding the sources of credit. The sources of loan can be broadly divided into institutional and non-institutional sources. The institutional sources include co-operatives, commercial banks, regional rural banks and various governments and semi-government institutes, while the, non-institutional sources include the endogenous money lenders (loan sharks), traders and merchants, friends and relatives, Self Help Groups, etc. Regarding financial inclusion of the unorganised enterprises, it is commonly assumed that the institutional (formal) sources denied providing loans to those enterprises. As a result, they

\section{Table 7: Per Unorganised Manufacturing Enterprise Estimated Value of Loan from Different} Agencies in Assam (in ₹)

\begin{tabular}{|c|c|c|c|c|c|c|c|c|}
\hline & & $\begin{array}{c}\text { All } \\
\text { Institutional } \\
\text { Sources } \\
\end{array}$ & $\begin{array}{l}\text { Money } \\
\text { Lenders }\end{array}$ & $\begin{array}{l}\text { Friends \& } \\
\text { Relatives }\end{array}$ & Others & $\begin{array}{c}\text { All Non } \\
\text { Institutional } \\
\text { Sources } \\
\end{array}$ & Total & FRG \\
\hline \multirow{2}{*}{$\begin{array}{l}1994- \\
1995\end{array}$} & Rural & 203 & 14 & 47 & 50 & 111 & 314 & 0.35 \\
\hline & Urban & 1844 & 64 & 6 & 97 & 167 & 2011 & 0.08 \\
\hline \multirow{3}{*}{$\begin{array}{l}2000- \\
2001\end{array}$} & Rural & 193 & 39 & 144 & 204 & 387 & 580 & 0.67 \\
\hline & Urban & 1012 & 168 & 122 & 158 & 448 & 1460 & 0.31 \\
\hline & Combined & 306 & 55 & 141 & 198 & 394 & 700 & 0.56 \\
\hline \multirow{3}{*}{$\begin{array}{l}2005- \\
2006\end{array}$} & Rural & 465 & 81 & 205 & 39 & 325 & 790 & 0.41 \\
\hline & Urban & 5064 & 261 & $*$ & * & * & * & $*$ \\
\hline & Combined & 933 & 99 & 252 & 83 & 434 & 1367 & 0.32 \\
\hline \multicolumn{9}{|c|}{$\begin{array}{l}\text { Sources: Compiled and calculated from Report No. 435: Assets and Borrowings of the } \\
\text { Unorganised Manufacturing Enterprises in India, NSS 51st Round, 1994-1995; Report No.479, } \\
\text { Unorganised Manufacturing Sector in India: Employment, Assets and Borrowings, NNS 56th } \\
\text { Round, 2000-2001 and Report No.525, Unorganised Manufacturing Sector in India: Employment, } \\
\text { Assets and Borrowings, NSS 62nd Round, 2005-2006 } \\
\text { *These data are not used as the data in the published report contradicts itself. (Report no.525, } \\
\text { Unorganised Manufacturing Sector in India: Employment, Assets and Borrowings; NSSO 62nd } \\
\text { Round of Survey) }\end{array}$} \\
\hline
\end{tabular}

From the Table 7, it can be seen that the source of credit for unorganised enterprises institutional sources plays an important role as in Assam over the years. Among the non- have to depend on the non-institutional sources, who exploit them by charging higher rates of interest. It is assumed that if an individual were able to have credit from institutional sources he would not move to a non-institutional source. In other words, institutional sources are the first choice of any borrower. Only if he were unable to have credit from institutional sources he would borrow from the non-institutional sources. Thus, when an entrepreneur borrows from the noninstitutional sources one can say that there is demand for credit, but the actual supplier (Formal Financial Institutions) is not in a position to fulfil his demand. The proportion of loan an individual borrow from the noninstitutional sources can be termed as the Financial Resource Gap (FRG). In other words, FRG explains the percentage of demand for credit could not be fulfilled by the existing supply. That the average amount of loan per enterprise had been borrowed from different sources are shown in Table 7. 
institutional sources, friends and relatives play the important role, followed by the endogenous money lenders. The rates of interest on loan taken from the noninstitutional sources are generally found to be higher than that on institutional sources. However, the loan taken from friends and relatives are interest free. Table 7 further shows that the FRG is declining over the years. Moreover, the FRG of the rural enterprises are higher than that of the urban enterprises. From the existing FRG, it can be concluded that still there is demand for credit; which could not be fulfilled with the existing supply arrangement.

It is also imperative to have an idea about the FRG of different types of unorganised enterprises in Assam (please refer to Table 8). However, Table 8 gives information only for 2005-2006, as data related to this issue are not available for rest of the years.

Table 8: Estimated Value of Outstanding Loan per Unorganised Manufacturing Enterprise (in ₹) from Different Agencies and the Financial Resource Gap in Assam during 2005-2006

\begin{tabular}{|c|c|c|c|c|c|}
\hline & & All Sources & Institutional Sources & Non- Institutional & FRG \\
\hline \multirow[t]{4}{*}{ Rural } & OAME & 174 & 10 & 164 & 0.94 \\
\hline & NDME & 1796 & 1213 & 583 & 0.32 \\
\hline & DME & 72990 & 53752 & 19238 & 0.26 \\
\hline & All & 790 & 465 & 325 & 0.41 \\
\hline \multirow[t]{4}{*}{ Urban } & OAME & 293 & 119 & 174 & 0.59 \\
\hline & NDME & 5928 & 3757 & 2171 & 0.37 \\
\hline & DME & 73057 & 64093 & 8964 & 0.12 \\
\hline & All & $*$ & 5064 & $*$ & $*$ \\
\hline \multirow[t]{4}{*}{ Combined } & OAME & 182 & 18 & 164 & 0.90 \\
\hline & NDME & 3271 & 2121 & 1150 & 0.35 \\
\hline & DME & 73022 & 58777 & 14245 & 0.19 \\
\hline & All & 1367 & 933 & 434 & 0.32 \\
\hline
\end{tabular}

Sources: Calculated from Report No.525; Unorganised Manufacturing Sector in India: Employment, Assets and Borrowings; NSS 62nd Round, 2005-2006

* These data are not used as the data in the published report contradicts itself. (Report no.525, Unorganised Manufacturing Sector in India: Employment, Assets and Borrowings; NSSO 62nd Round of Survey)

From the data in Table 8, it is apparent that the smaller the enterprises are, more dependent they are on the non-institutional sources for credit. For example, during 2005-2006 the FRG of the OAME taken together is 0.90; while that of NDME and DME is 0.35 and 0.19 respectively. The overall FRG for all the unorganised enterprises taken together is 0.32 . Similarly, the FRG of the enterprises in the rural areas is higher than those in the urban areas. Thus, it can be concluded that FRG decreases as the size of the unorganised enterprise increases and rural enterprises have higher FRG. In other words, smaller as well as the rural unorganised enterprises depends more on the noninstitutional sources of credit.

\section{Conclusion}

The above discussion makes it clear that in Assam, larger percentage of unorganised enterprises over the years stated lacking of adequate amount of capital as the constraint faced by them. Again, the average amount of loan taken by the unorganised manufacturing enterprises in Assam is smaller than that of allIndia average. In Assam, the FRG is higher for the enterprises in the rural areas as compared to those in the urban areas. Thus, those enterprises in the rural areas are more dependent on the informal sources of credit as compared to those in the urban areas. Moreover, the smaller enterprises have limited access to credit from the formal financial institutions compared to the larger enterprises. 
Hence, it can be concluded that there is demand for credit from these enterprises; but the formal financial institutions are not in a position to fulfil their demand. Therefore, they are dependent on the non-institutional sources of credit. For these reasons, the policies regarding financial inclusion of the unorganised manufacturing enterprises should be such that would be able to fulfil the credit needs of the smaller unit of unorganised enterprises, especially those in the rural areas.

\section{References}

Allen, F., R Chakrabarti, Sankar De, J. 'QJ'Qian, and M. Qian (2006), Financing Firms in India, Policy Research Working Paper No WPS3975, World Bank, Washington DC.

Bhalla, Sheilla (2009), 'Definition and Statistical Issues Relating to Workers in Informal Employment', National Commission for Enterprises in the Unorganised Sector, Government of India, New Delhi, January.

Bhavani, T. A. (2006), Globalisation and Indian Small Scale Industries: Technology and Competitiveness. New Delhi: Ane Books.

Bhavani, T. A. and N. R. Bhanumurthy (2012), Financial Access in Post-reform India, Oxford University Press, New Delhi.

Haris, J. R. and M. P. Todaro (1970), 'Migration, Unemployment and Development: A Two Sector Analysis', American Economic Review, March, Pp- 126- 142.

Honorati, M. and T. Megistae (2007), Corruption, The Business Environment and Small Business Growth in India, Policy Research Working Paper No. WPS4356. World Bank, Washington DC.

NSSO (2001), Informal Sector in India 19992000, Salient Features, NSS 55th Round (July 1999- June 2000), Ministry of Statistics and Programme Implementation, Government of India.

Ray, Debraj (2000), Development Economics, Oxford University Press, New Delhi, Chapter-14, Pp-529 to 589
Subramanian, A. (2012) 'Breaking the Glass Ceiling: Unleashing the Potential of the Informal Sector', Malhotra R. (ed), A Critical Decade: Policies for Indian's Development, Oxford University Press, New Delhi.

Tendulkar, S. D. and T. A. Bhavani (1997) 'Policy on Modern Small Scale Industries: A Case of Government Failure', Indian economic Review, 32(1): 39-64.

World Bank (2008), Finance for All: Policies and Pitfalls in Expanding Access, Washington D.C.

\section{Acknowledgement}

I am grateful to the reviewers for comments on an earlier version of this paper.

\section{About the Author}

Mr. Prasenjit Bujar Baruah completed his graduation from B. Borooah College, Guwahati and Masters in Economics from Gauhati University, Guwahati. Then he did M. Phil. in Economics from University of Hyderabad, Hyderabad. He worked as assistant professor in Economics in Bijni College, Bijni and Dispur College, Dispur (Guwahati). Presently he is serving as an Assistant Professor, Department of Economics, Rajiv Gandhi University, Itanagar and also pursuing Ph.D from Gauhati University, Guwahati. His area of specialisations is macroeconomics, monetary economics and development economics. So far, he has published one book on micro-finance and a number of articles and research papers in various journals and edited volumes. 